\title{
Ecosystem Services Provided by the Little Things That Run the World
}

\author{
Olga Maria Correia Chitas Ameixa, \\ António Onofre Soares, Amadeu M.V.M. Soares and \\ Ana I. Lillebø
}

Additional information is available at the end of the chapter

http://dx.doi.org/10.5772/intechopen.74847

\begin{abstract}
Highest extinction risk and consequently biodiversity loss are predicted to occur in invertebrates, specifically insects, and these declines are expected to cascade onto ecosystem functioning and human well-being. Although this knowledge is intrinsically present in more traditional communities, in more urban environments, mapping ecosystem services can be an important tool to raise people's awareness on the importance of preserving insect diversity. After an extensive revision of the available literature, we used a rule-based approach to assess the provisioning, regulating and maintenance, and cultural services delivered by insects. We followed the Common International Classification of Ecosystem Services (CICES) and identified several potential indicators that may help underpin the mapping and valuation of the services delivered by insects. From our search, we extracted a total of 73 indicators, divided as 17 Provisional indicators, 27 Regulation and Maintenance indicators, and 29 Cultural indicators. We concluded that insects are providers of services in the three major 'Sections' of ecosystem services defined by CICES. Despite the lack of recognition of provisioning and cultural services, the indicators provided may help to raise awareness on the importance of the little things the run the world, in order to preserve traditional and technological uses of insects and their services.
\end{abstract}

Keywords: ecological function, ecosystem services, insects, natural capital, services indicators 


\section{Introduction}

The highest extinction risk and consequently the greatest biodiversity loss are predicted to occur in invertebrates [1, 2], specifically insects, and these declines are expected to cascade onto ecosystem functioning and human well-being [2]. For this reason, mapping ecosystem services provided by insects can be a way to raise people's awareness on the importance of preserving insect diversity.

From 1 million species described, only 5000 are considered harmful to crops, livestock, or humans [3], the so-called dis-services [4]. However, it also widely acknowledge the benefits that insects might directly or indirectly bring to humans, namely through pollination, pest control, raw materials, or as food, known as ecosystem services (ES). Moreover, there are clear evidences of the growing importance of insects as feed and food resources, especially in the context of the global population growth and to overcome the global scarcity of proteins [5] or even in the context of new drugs discovery for by pharmaceutical industries, e.g., [6, 7, $8]$, with insects having a prominent role in the provisioning services by ecosystems. Insects produce a huge number of defensive secretions against predators, and these molecules are potentially medicinal drugs, e.g., [7, 9]. In countries such as China, about 77 species from 14 families and belonging to 8 orders have been used in traditional medicine to treat tumors and cancer [10].

Due to the growing interest regarding this class as key mediators of ES, i.e., there is a growing demand for ES mediated by insects; there is also the need to assess and map the supply of ES that is mediated by insects and provided in the habitats they populate. The demand for ecosystem services is socio-economically driven [11], while the supply is underpinned by ecosystems process and functions [12]. In this context, this work proposes to deliver a set of potential global indicators for ES mediated by insects that can serve as a foundation for mapping and assessment of ES at local/regional, national, or even transnational levels. The use of indicators has been recognized as a useful communication tool that facilitates the simplification of human-environmental systems high complexity, e.g., [13]; they can be selected for mapping and assessment of ES [14] and to support specific management purposes involving ES trade-offs [15]. This work may also be seen as a contribution to the EU Biodiversity Strategy for 2020, Action 5-Improve knowledge of ecosystems and their services in the EU, which is linked to other global initiatives to protect biodiversity, namely International Platform of Biodiversity and Ecosystem Services (IPBES) and to the UN Natural Capital Accounting. In this sense, we performed an extensive review of the available literature to assess the supply side of ecosystem services, which results directly or indirectly from insect-mediated processes and functions. The ES classification followed the Common International Classification of Ecosystem Services (CICES) that considers three major categories: provisioning, regulating and maintenance, and cultural services in order to avoid natural capital double counting [16]. CICES has been applied to habitats, e.g., [17], to social-ecological systems, e.g., [18], or with the purpose of supporting the mapping and assessment of ES at EU Member States (Action 5 of the Biodiversity Strategy), e.g., [14]. Results from this rule-based review are presented and discussed according to the lowest possible CICES category. 


\section{Methodology}

The ES provided by insects was categorized according to the CICES classification [16], which the latest full version can be downloaded at http://cices.eu/. In this review, we applied the CICES rationale to the world's most abundant and diverse group of organisms and acknowledge their role as major agents of the ES provided in the ecosystems where they live. Following the same principle as the MAES working group [14], we provide a set of potential indicators for each identified service, which might help underpin the mapping, valuation, and management of the delivered services.

The services were categorized to the maximum possible resolution following CICES hierarchical structure whenever possible. If sufficient data were not available, the next higher level of resolution was chosen.

We used a rule-based approach to map indicators for ES. We did this by first reviewing and summarizing existing scientific and nonscientific literature related to ES provided by insects. Our aim was to extract from the literature and by using CICES rational, to classify potential indicators that can be used to assess and map these services in different ecosystems and across different geographic regions.

The literature search was performed in specific scientific libraries (e.g., Scopus and Web of Knowledge), using the keywords (single and in combination): ES, insects, ecological function, pollination, seed predation, biological control, decomposition, seed dispersal, food, feed, materials, medicines, society, and ecosystems. However, there were many gaps for several ES categories in these referenced libraries. For this reason, we enlarged our search to include books and nonresearch literature. This approach was especially important to access the cultural services, for which available scientific literature is scarce. In fact, evidences seem to show that inclusion of nonresearch literature can be useful to validate the results of a research-based literature search [19]. In our case, we definitely would have biased our conclusions if we had excluded nonresearch-based literature, even if this only makes up $25 \%$ of all searched literature, mainly because cultural services are rarely considered in ES assessments [20]. Actually, cultural services do not represent purely ecological phenomena but rather are the outcome of complex and dynamic relationships between ecosystems and humans [21], and for this reason, we needed to adapt our bibliographic review in order to include cultural services and produce valid potential indicators. In total, we used 90 papers indexed in Scopus, 21 authored and 1 edited books, 16 chapters, 13 reports, 7 proceedings, 8 papers not indexed in Scopus, 7 electronic articles, 3 thesis, and 8 webpages.

\section{Results}

In this section, a short description of each of the headings corresponds to CICES hierarchical structure identified for ES mediated by insects, while the corresponding indicators for mapping and assessment are presented in Table $\mathbf{1 .}$ 


\section{CICES hierarchical}

Relevant examples

Potential indicator(s) structure

\section{Provisional}

\subsection{Nutrition}

\subsubsection{Biomass}

1.1.1.1. Reared and wild animals and their outputs for direct consumption

1.1.1.2. Wild animals for indirect consumption

\subsection{Products}

\subsubsection{Biomass}

1.2.1.1. Insects products for direct use or processing
Reared insects for Human nutrition

Wild insects collected for direct Human nutrition

Wild insects predated by animals (fish and game birds) that are used in Human nutrition

Insect species that can be incorporated in food production systems.
Number and distribution of insects farms of edible species

Honey consumption from domesticated and wild bees

Number, distribution and biomass of species consumed by humans

Number and distribution of insects predated by animals (fish and game birds) used in Human nutrition

Insect's number and biomass used in food production for Human nutrition
Products made with insect materials

Medicinal uses of insects and their derived products for humans

Insects used by animals as medicines
Amount and distribution of bee products (e.g., honey and beeswax production), and other insect products by category (e.g., silk, pigments, lac production).

Amount and distribution by category of medical/ pharmaceutical active substances)

Number and distribution of animals which rely on insects as medicines

Number and distribution of species which clean/ decompose wastes
2.1. Mediation of waste, toxics and other nuisances

2.2. Mediation of flows

2.2.1. Mass flows

2.2.1.1. Mass stabilization and control of erosion rates

2.3. Maintenance of physical, chemical, biological conditions

2.3.1. Lifecycle maintenance, habitat and gene pool protection
Bio-remediation

Decomposition

Contribution for soil erosion mitigation by influence on the soil structure due their activities
Number and distribution of species which contribute to soil erosion mitigation 


\section{CICES hierarchical structure}

2.3.1.1. Pollination by insects

\subsubsection{Seed dispersal by insects}

2.3.1.3. Maintaining nursery populations and habitats

\subsection{Maintenance of} physical, chemical, biological conditions

2.4.1. Pest and disease control

\subsubsection{Pest control}

2.5. Maintenance of physical, chemical, biological conditions

\subsubsection{Soil formation and} composition

2.5.2. Decomposition and fixing processes

\section{Cultural}

3.1. Physical and intellectual interactions with insects

3.1.1. Physical and experiential interactions

\section{Relevant examples}

Pollinators of wild plants and cash crops

Dispersal of seeds by insects

Wild insect species which serve as food for other predators e.g., fish, birds, spiders, lizards, bats, etc.

Biological control of different types of pests

Termites, ants and dung beetles

Decomposition of dead organic material

\section{Herbivory}

Nutrient cycling

\section{Potential indicator(s)}

\section{Number and distribution of pollinator species;}

Number and distribution of plant species which depend on insects to reproduce and that are used for human consumption

Number and distribution of beehive's renting for pollination

Number and distribution of species that promote seed dispersal

Number and distribution of plant species which depend on insects for seed dispersal and that are used for human consumption

Number and distribution of insect species that are predated by insectivorous species.

Number and distribution of insectivorous species that are used for human consumption

Number and distribution of biocontrol agents

Effective biological control reported cases

Number and distribution of insect species involved in pedogenese and soil bioturbation

Number and distribution of insect species that decompose dead organic material, contributing to nutrient cycling and soil fertility and which can influence the rate of decomposition (herbivory).
Observation of insects and insect dependent wildlife.

Activities related with wildlife which rely on insects as a critical nutritional resource, e.g., hunting, fishing
Number and distribution of Citizen Science projects related with insects;

Number of internet groups related with insects, which share pictures and other information.

Number and distribution of insectivorous game and game species 


\begin{tabular}{lll}
\hline $\begin{array}{l}\text { CICES hierarchical } \\
\text { structure }\end{array}$ & Relevant examples & Potential indicator(s) \\
\hline $\begin{array}{l}\text { 3.1.2.1. Scientific } \\
\text { Amount of scientific study } \\
\text { areas in which insects are } \\
\text { subject matter of research }\end{array}$ & $\begin{array}{l}\text { Number of scientific studies using insects as subjects } \\
\text { of research. } \\
\text { Studies listed in Database Platforms, e.g., ISI Web of } \\
\text { Knowledge. }\end{array}$ \\
& $\begin{array}{l}\text { Number of insect biological model systems } \\
\text { Bioindication }\end{array}$ & $\begin{array}{l}\text { Number and distribution of species used in forensic } \\
\text { studies }\end{array}$ \\
& $\begin{array}{l}\text { Number and distribution of insect species which are } \\
\text { bioindicators of ecological condition }\end{array}$ \\
3.1.2.2. Educational & Activities using insects in kindergartens and \\
educational programs & Number of websites devoted to insect information \\
& Number of citizen science projects using insects \\
3.1.2.3. Heritage and & Number of insect zoos
\end{tabular}

\subsubsection{Entertainment}

3.1.2.5. Esthetic

3.2. Spiritual, symbolic and other interactions with insects

3.2.1. Spiritual and/or emblematic (sacred and/or religious)

\subsubsection{Symbolic}

3.2.1.2. Sacred and/or religious

3.2.1.3. Other cultural outputs (Existence and bequest)
Movies, books, TV series, magazines, social internet groups

Inspiration for painters, photographers and other artists interested in insects
Ex-situ viewing/experience of natural world through different media. Videos, documentaries on insects.

Mass media indicators: TV and magazines, Web sites, social networking sites; Movies

Different types of artifacts in which insects are used Number of visits to artistic exhibits
Emblematic insects (e.g., U.S., state insects or state agricultural insects)

Scarab cult, cicadas as symbols of rebirth

Entomological organizations, insect collections
Number and/or distribution of symbolic insect species

Number of sacred species; insect species that sustain supernatural believes

Number and distribution of entomological organizations, insect collections, zoos, museums, and butterfly gardens, colleges and universities where entomology can be studied.

ONG's involved in sustainable insect collection by local populations.

Table 1. Potential indicators for ES delivered by insects following the CICES hierarchical structure. 


\subsection{Provisioning-nutrition and biomass}

\subsubsection{Wild and reared insects and their outputs for direct consumption by humans}

Insects are part of human diet in many parts of the world, and it is estimated that at least 2 billion people worldwide regularly consume insects [22]. Most of this consumption occurs in central and southern Africa, Asia, Australia, and Latin America and can provide 5-10\% of the annual animal protein consumed by various indigenous groups as well as fat and calories and various vitamins and minerals [23, 24]. Jongema [25] compiled a list of edible insects, where 1900 edible insect species were reported. In Figure 1, the percentage of insects eaten grouped by their orders is compiled.

Recently, several "entomophagic" movements have appeared in order to introduce insects in daily diets, with entomologists and chefs joining together to introduce insects as gourmet food items, e.g., [26]. These movements have the blessing and active participation of Food and Agriculture Organization (FAO), which supported several actions on edible insects worldwide in recent years. According to FAO, scarcities of agricultural land, water, forest, fishery and biodiversity resources, as well as nutrients and nonrenewable energy, are foreseen. In this context, insects appear as an alternate form of having a source of protein and other nutrients without the depletion of resources like in livestock production systems.

Besides direct consumption of insects, honey is the most widely insect output consumed by humans. Worldwide, the EU accounts for approximately $20-25 \%$ of global consumption (amounted to 310 thousand tonnes in 2007). The other two major consumers of honey in the world are China (15\%) and the USA (10\%) [27].

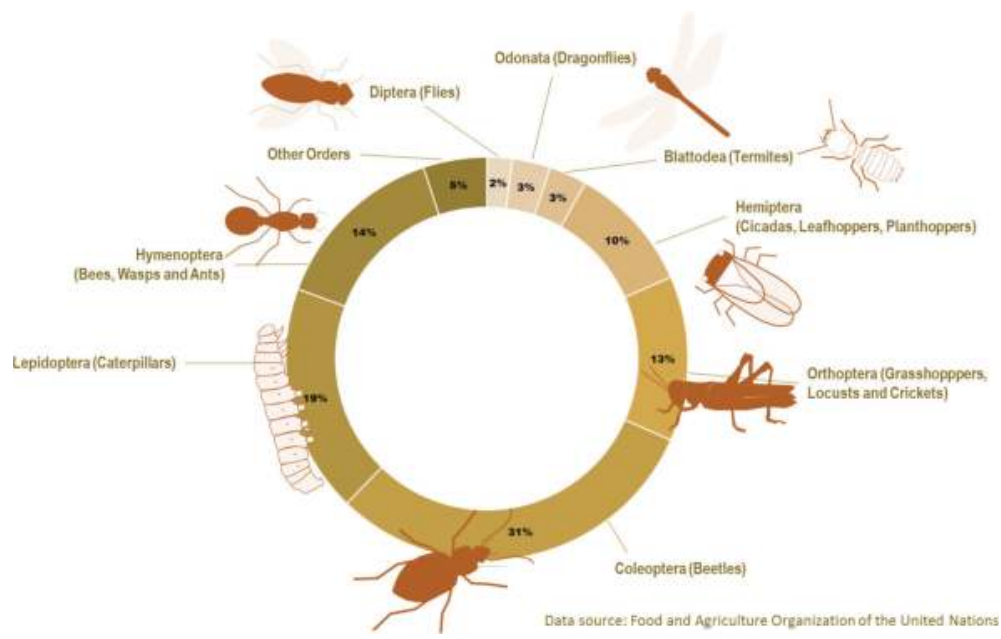

Figure 1. Percentage of insects eaten according to their order. 


\subsubsection{Wild insects for indirect consumption by humans}

Several animals feed primarily or exclusively on insects; and some of these animals are important food sources for humans [28]. Numerous insect orders have been used as complementary food sources for poultry [29]. Terrestrial invertebrates can comprise more than half of energy ingested by stream fishes [30,31] and are often the preferred prey of juvenile salmonids [32] with significant consequences for fish growth and abundance [33, 34]. Insects falling into streams are estimate to comprise about $30-80 \%$ of the diets of young salmon [31], 56.7\% of masu salmon, $50.5 \%$ of white-spotted char, $46.3 \%$ of rainbow trout, $22.6 \%$ of Dolly Varden, and $12.0 \%$ of sculpin diets [35]. Even in systems where invertebrates made up only 10-15\% of the terrestrial input, they comprised in total more than a third of the diet [36], which seems to be an indication that stream fish often prey selectively on terrestrial invertebrates falling into the water, e.g., [37].

Chicks of most game birds (e.g., quail, rouse, and pheasant) feed mainly on insects and other invertebrates, because of the high protein content, essential for the birds' rapid development [38]. Apparently, many chicks are not able even to digest plant material [39].

\subsubsection{Insect products for direct use or processing}

Bees produce six hive products - honey, pollen, royal jelly, beeswax, propolis, and venomall of which are collected and used by people for various nutritional and therapeutic purposes. Honey is the most well-known and economically important hive product. The first written reference to honey appeared in a Sumerian tablet writing, dating back to 2100-2000 BC, that mentions honey's use as a drug and an ointment [40]. Bees deliver about 1.2 million tons of commercial honey per year [5]. Honey and beeswax, whose trade dates back to ancient Greece and Rome, were used in Medieval Europe as trade goods and as payment for taxes [41]. Beeswax is popular for making candles, adhesives, seals, and molds for casting [42]. It is also used as wood polish and is one of the most commonly used waxes in cosmetics.

Wax can also be produced by scale insects (Hemiptera, superfamily Coccoidea). The Chinese insect wax, or just insect wax, is produced by Ceroplastes ceriferus [43], which is common in China and India, or Ericerus pela, which is distributed in most parts of China, Japan, and the Korean peninsula, where it has been bred for over 1000 years [44]. Chinese insect wax has been used as a substitute for beeswax and is also used for candles, wax paint, polishing leather, and sizing paper [45]. Scale insects are also the main source of commercial shellac, also known as lac. The lac scale Kerria lacca (Kerr, 1782) can be found in the forests of India and Thailand and secretes shellac a natural mixture of resin and wax [46]. The propagation, care, and harvest of the raw lac product are largely dependent on tribal people scattered throughout forested areas. For these people, lac cultivation and harvest can be a substantial source of monetary income [47]. Lac has been an integral part of Indian history and culture for thousands of years, beautifying wood as a coating or used as a thermoplastic molding material [47]. It can also be used as a red colorant for dying natural fibers [48], e.g., wool in Persian carpets dated as early as 714 B.C [47]. Shellac wax is used in crayons and lipstick, as well as polishes and waxes for furniture [47]. Shellac can also be used as an electrical insulator, as well as a binder for man-made abrasive grinding wheels used in the crystal cutting and polishing industry [47]. Shellac was an ingredient in the production of gramophone records, until vinyl took its place [49]. 
As it is a natural, nontoxic resin, shellac can be used in the food industry as a colorant or coating [50]. In the perfume industry, it is used for its ability to microencapsulate, allowing a timed release of perfume in lotions and other beauty products [48].

Scale insects still provide carmine, also called cochineal, a red dye mainly produced by Dactylopius coccus. This dye is used since pre-Columbian civilizations, as early as 2000 years ago, and was once one of the most valuable exports from colonial Mexico [51]. Carmine is used to color foods, textiles, and pharmaceuticals [5]. For three centuries, the English, French, and Dutch resorted to espionage, piracy, bribery, and theft to learn the secret of this fabulous dye and break Spain's monopoly [52]. When the FDA banned Red Dye No. 2 in 1976, many food and cosmetics producers returned to cochineal, which is neither a toxin nor a carcinogen. Sometimes listed as carmine or E120, cochineal is the only natural red food coloring authorized by the FDA [52].

Before the discovery of $D$. coccus, red dyes were obtained from other scales species. Kermes (from Kermes vermilio Planchon) was used in Europe since Roman times [53]. In central and northern Europe, the Polish cochineal (from the Porphyrophora polonica) was used throughout middle age [54]. Besides these, Armenian cochineal (from Porphyrophora hamelii Brandt) was collected from the base of its hosts Aeluropus littoralis Gouan or Phragmites communis Trin., and occurred in Armenia, Turkey, and Iran [55].

One of the most important insect products is silk. Sericulture has been practiced at least since 2000-3000 B.C. in China and is among the most widely traded commercial products. The historic importance of sericulture is demonstrated by the Silk Roads that connected Europe, the Middle-East, and China [41]. Silkworms remain the only source of silk and produce more than 90,000 tons of this natural protein fiber per year [56]. However, silk production is not confined to China. Indeed, in Madagascar, wild silk commonly termed "Landibe" was exploited long before the introduction of "Chinese silk" from Bombyx mori during the 19th century [57, 58]. Wild silk in Madagascar has many origins, with many silk producing species being present on the island. One of such species is Borocera cajani [59]. Historically, the Madagascan population used B. cajani silk to create sumptuous shrouds. Although sericulture in Madagascar plays a minor role at international level [57], it remains a major source of income for more than 10,000 local families working in the silk industry [60].

Iron gall ink, also referred to as iron gallotannate ink, is one of the most important inks in the history of western civilization and was in widespread use from the middle age until the twentieth century, with a significant part of our cultural heritage recorded with it [61]. For instance, Bach used it to write down his music, Rembrandt used it for his drawings, while Thomas Jefferson wrote the Declaration of Independence with it [61]. However, this ink presents some corrosive properties, reason why several historical artifacts suffer from its corrosive action. Examples are the original complete works of Victor Hugo which are almost destroyed, while $60-70 \%$ of Leonardo da Vinci's work shows signs of deterioration [62].

The use of insects and derived products as medicines has a long tradition in many parts of the world and in many cultures, e.g., in Chinese medicine, Indian Ayurvedic medicine, Australian Aborigines, as well as in Africa and South America. Science has provided evidence of immunological, analgesic, antibacterial, diuretic, anesthetic, and antirheumatic properties [63]. 
Extensive reviews regarding the use of insects in medicine are provided by Cherniak [6] and Dossey [7], which include details of the use of medicinal insects throughout the World and aspects of their potential for drug discovery. Ratcliffe et al. [8] provided an overview of significant recent developments in bioengineering natural products from insects, describing use or potential use in modern medicine, as well as the use of insects as models for studying essential mammalian processes such as immune responses to pathogens. Examples of these "rediscovered" products come from bees. Honey has been used for a long time as wound dressing by several different cultures in different parts in the world (a good historical review is provided by Jones) [64]. Another review by Molan [65] demonstrates that honey, the oldest wound dressing material known to medicine, can give positive results where the most modern products are failing, mainly due to its reported antimicrobial and anti-inflammatory activities.

Several properties were reported for royal jelly as well, and these included anti-cancer metastasis [66], neurite growth stimulation [67], and anti-allergic responses [68],

Apart from these, a broad spectrum of biological activities have also been reported in studies using propolis, such as antioxidant [69], antibacterial, antiviral, antifungal [70], anti-inflammatory [71], and anticancer effects [72]. Currently, the pharmaceutical industry uses beeswax as a binding agent, time-release mechanism, and drug carrier [43].

Chinese wax has also been employed medically. Taken internally, it has been used as a remedy for hoarseness, worms, and nervousness and to aid the mending of broken bones. Externally, it has been used as an ointment for treatment of wounds [73].

If we think about cancer and the side effects of current treatments, we definitely have to account for knowledge of traditional medicine, such as in Chinese medicine where several kinds of insects have been traditionally used to treat tumors and cancer [10]. Insects produce a huge number of defensive secretions against predators, and these molecules are potentially medicinal drugs, e.g., [7]. For instance, cantharidin, a defensive alkaloid produced by blister beetles (Meloidae) that is used commercially to remove warts [74], has been shown to kill a variety of tumor cells in vitro as well as in animal models in vivo (reviewed by [8]).

Ant venom was the subject of U.S. patent 4,247,540. This came about through a medical study at the Miami School of Medicine, where ant venom had an effect on painful and inflamed joints [9]. In fact, besides ailment treatment, ants were also used for diagnosis, as in the case of an old observation, made by tribes in the Amazon forest that ants will swarm over the urine of diabetics but will leave ordinary urine alone [9]. In fact, ants are widely used worldwide: in Africa, they are used to treat whooping cough, in Morocco to overcome lethargy, Australian aborigines used them to treat headaches, in South America to cure colds and impotence in men, and in Russia, a tincture of ants known as "muraschkowka," was used to treat colds. In Tibetan medicine, ants were used for urinary retention and as a mild purgative, and in Central Asia, its main use was for curing arthritis [9]. Lockhart [9] refers to Old European literature that contains recipes for "eau de magnanamite" used to treat sore eyes and in Arabian medical literature, where ants were used to treat the victims of the rutaila spider bite, leprosy, and as an aphrodisiac is described. 
Ant mandibles were used to stitch wounds of surgical incisions-a practice documented in India as early as 1000 B.C., using live ants to bite the pinched sides of a wound or incision, leaving the mandibles fastened until the wound heals [75], a practice also used in the Mediterranean area but discontinued due to some criticism of some European doctors [9].

One of the well-studied medical applications of arthropods is the use of maggots [6]. Blow fly (Lucilia spp.) maggots, used in traditional medicine to remove necrotic tissues without surgery, received renewed medical attention for wound debridement, as surgical treatments increase the risk of infection by antibiotic-resistant pathogens [76-78].

Besides its economic value as a product, silk has been prescribed in traditional medicine as well. Silkworm larvae infected with fungus are one of the most used sources of medicine in Korean medicine and, according to Pemberton [79], are used to treat stroke, tonsillitis, and rubella among other diseases, while adult male silkworm moths are used to treat impotence and premature ejaculation. Additionally, silkworm larvae frass were also used to treat diabetes, neuralgia, and skin rash, among other conditions [80]. In fact, powdered silkworm larvae were tested and shown in modern bioassays to inhibit absorption of glucose in human intestinal epithelium cells [81]. More recently, due to its unique properties, silk fibroin, a naturally occurring protein polymer, was shown to be a favorable matrix for the incorporation and delivery of a range of therapeutic agents [82]. Besides silk, other insect proteins are also used in medicine. For instance, resilin, a rubber-like protein that enables insects to jump (e.g., fleas), has been used in medicine to repair arteries taking advantage of its elastic properties [83].

Shellac has also been used for a long time in Ayurvedic medicine [47] and more recently in modern pharmaceuticals as a tablet coating [84] and in dental medicine [85].

The anticoagulants and other components in the salivary glands of blood-sucking insects, for example in horseflies, have been used for hundreds of years as anti-thrombosis treatments in Eastern Medicine [86].

Recently, the importance of insects as source of natural products has been recognized by several pharmaceutical companies which set up to exploit these substances using modern molecular and biochemical techniques [8]. Furthermore, since 2009, the Chinese Government began to invest more than 12 billion US dollars over 5 years in new drug development, and insects as potential sources were not neglected [8].

Not only humans use insects to treat their ailments, animals do it as well. The use of ants by bears suffering from abdominal complaints is referred by the Roman writer Plutarch [9]. In 1935, Erwin Stresemann invented the term "anting," which refers to bathing in ant nests [9]. Nowadays, the behavior involves the bird seizing one or more ants in the bill and then, while holding one or both wings outstretched and the tail bent forward between the legs, wiping the ants into the primary feathers of wings and tail [87]. It is believed that birds use ants to maintain their feathers free from parasites, such as feather lice Mallophaga species and feather mites Acarina species [9], although this is not a consensual belief [88]. Anting has been reported for over 200 species of birds, mostly passerines (reviewed by [87]). The ants are typically Formicinae, which spray formic acid as a defense, or Dolichoderinae, which exude a repugnant anal fluid. Anting was also reported in some mammals, e.g., for capuchin monkeys [89] and 
gray squirrels [90]. European farmers also feed chickens with large red ants, as well as ant eggs, since these are considered powerful stimulants of egg production. Farmers would feed these to broody hens and "lazy layers." Feeding ant eggs to chicken results in weight gain with fat loss and seems to prevent diseases like coccidiosis and enteritis (see [9]).

\subsection{Regulation and maintenance}

\subsubsection{Mediation of waste, toxics, and other nuisances}

When cattle was introduced to Australia in 1788, waste biodegradation became an immediate problem as endemic dung beetles, adapted to marsupial dung, were simply insufficient to decompose the increased amounts of manure [91]. To solve this problem, dung beetles were introduced to Australia from South Africa, Europe, and Hawaii. Of 46 introduced species, 23 successfully established [5]. These beetles, from the insect families Scarabaeidae and Geotrupidae, bury dung under the soil surface and reduce the associated nuisances with it. These nuisances include a decrease in palatability of plant material that is fouled with dung and increase of diseases, since many cattle parasites and pest flies require a moist environment such as dung to complete their development [92]. Losey and Vaughan [28] estimated the annual value of dung burial by dung beetles in the US in US $\$ 380$ million. The use of dung is not restricted to beetles. For instance, the Hawaiian big-headed ant Pheidole megacephala accidentally introduced to Fiji also gets into the droppings of animals [9].

In aquatic ecosystems, insects falling into freshwater waterbodies influence the nutrient availability, since they add substantial amounts of carbon, nitrogen, and phosphorus to these nutrient-poor ecosystems and affect aquatic community dynamics [93-95]. In addition, the different functional groups (scrapers/grazers, shredders, and collector gatherers) living in aquatic systems contribute to the integration of nutrients from terrestrial sources.

\subsubsection{Mediation of flows}

\subsubsection{Mass stabilization and control of erosion rates}

It is well documented that the reduction in activity and biodiversity of the soil biota, which includes insects, leads to the degradation of the soil structure and increase of runoff and erosion. Soil biota influence soil properties through formation of stable aggregates and development of organomineral complexes and bonding through fungal hyphae and polysaccharides [96]. Soil properties can also be improved by mixing soil with organic residues and by turnover through burrowing and the formation of subterranean chambers and feeding galleries. These activities improve macroporosity and continuity of pores from surface to the subsoil and increase the infiltration rate, which contributes to the reduction of runoff rate and amount [96]. Some examples of insects that influence soil structure are, e.g., termites, ants, dung beetles, and other burring insects.

\subsubsection{Maintenance of physical, chemical, and biological conditions}

\subsubsection{Pollination}

The Convention on Biological Diversity (CBD) has recognized pollination as a key driver in the maintenance of biodiversity and ecosystem functions [97]. Insects play a central role 
in most plant species reproduction, since the majority of all known pollinator species (98\%) are insects [98]. Over $90 \%$ of the 250,000 flowering plant species depend on pollinators. Not only natural ecosystems benefit from pollination, many cash crops are actually self-sterile and require cross-pollination to produce seeds and fruit [99]. But it is not only self-sterile varieties that benefit from cross-pollination, self-fertile varieties also produce more and better quality seeds and fruits, if they are cross-pollinated [99]. In fact, this is true for three-quarters of the 100 crop species that generate most of the world's food [98]. It is estimated that domesticated bees alone pollinate $15 \%$ of these species [5]. However, in recent years, there has been a worldwide decline in pollinator insects, mainly bees, which has made the world headlines, since this presents a serious threat not only to terrestrial ecosystems but also for agricultural production and ultimately for life on earth.

A good example of the lack of pollinators in agro-ecosystems can be seen in the Hindu KushHimalayan region (extends $3500 \mathrm{~km}$ over all or part of eight countries from Afghanistan in the west to Myanmar in the east). Typically, native wild bees, which, unlike the European honey bee Apis mellifera, are able to tolerate seasonal low temperatures and play a vital role in pollination of mountain crops and wild flora [100]. Among these are A. dorsata, A. florea, A. laboriosa (bees whose products can be collected but which cannot be kept in hives), and A. cerana (which can be kept in hives) [101]. However, these native bee species are imperiled nowadays due to changes in agricultural practices and due to competition with the introduced Apis mellifera. In the Hindu Kush-Himalayan region, agriculture is in a stage of transition from traditional cereal crop farming to high-value cash crops such as fruits and vegetables. This ongoing transformation poses a number of new challenges, including low production or crop failure due to inadequate pollination [101]. In fact, despite increasing agronomic inputs, the negative effects on pollinators have further contributed to the low yields [99]. To overcome this problem, in some areas (Maoxian County, China), farmers resorted to hand pollination of apples and pears [102]. However, in Pakistan, farmers started to cut down their trees [103].

More than $80 \%$ of the world's almonds are produced in California [104], which requires about half of the introduced Apis mellifera population in the US for pollination each year (NRDC, [105]). In addition, this provides beekeepers with lucrative pollination fees and a major source of income by renting their beehives [106], besides honey production.

Numerous other cash crops are $90 \%$ dependent on honey bee pollination, e.g., avocados, blueberries, cherries, cranberries, and sunflowers [107]. Pollinators are also required for seed production of many other crops such as soybeans, hay, and forage crops [108, 109], with a clear impact on beef and dairy products production.

A recent international study revealed that non-bee insects are valuable pollinators as well, with better performance in fruit set in crops and more resilient to landscape changes [110].

\subsubsection{Seed dispersal by insects}

One of the best examples of seed dispersal by insects is given by ants carrying seeds into their nests. Some plants even produce seeds with special coating with the purpose of being eaten by the ant or other phytophagous insect without damaging the seeds viability [111]. This behavior is not exclusive to ants, and it is also carried out by a phytophagous insects, mostly, coleopterans [78]. 
By burying seeds with dung, dung beetles are instrumental in sandy areas, in which they live [112]. Other insects can disperse seeds inadvertently, in which dispersal occurs with the help of gripping organs (hooks, teeth, viscous hairs, etc.). The seeds attach themselves to the insect's body and later fall to the ground, allowing new plants to germinate some distance away from the original plant [113]. By burying seeds, ants and dung beetles also protect them from being eaten [114].

\subsubsection{Maintaining nursery populations and habitats}

In natural ecosystems, besides fishes (Section 3.1.2), there are other riparian consumers that benefit from energy transfers gained from aquatic insects emerged from streams [115-117]. Aquatic insects provide significant seasonal subsidies to forest birds during the defoliation period, accounting for $50-90 \%$ of the monthly energy budget in half of the species. This contribution of aquatic prey to the annual, total resource budget differed among bird species, being estimated in $38.6 \%$ for great tit, $31.9 \%$ for nuthatch, $7.4 \%$ for marsh tit, and $9.5 \%$ for pigmy woodpecker [35]. Besides birds, emerged aquatic insects provide important subsidies for other predators such as spiders [118], lizards [119], and bats [119]. In fact, these groups do not rely only on aquatic insects, for instance, Lacki [120] found remains of 10 insect orders in fecal pellets of insectivorous bats.

This shows a huge potential for the incorporation of insects into the food production chain of food animals like poultry or in aquaculture [5].

\subsubsection{Pest control}

Biological control was practiced in China as early as the third century A.D., where ants were sold for the control of citrus insect pests [121]. However, the first widely successful biological control program was the introduction of the coccinellid, Rodolia (Vedalia) cardinalis which saved California's citrus industry, by controlling the cottony cushion scale, Icerya purchasi [122]. This example of classical biological control was the prelude for other introductions to fight pests all over the world, without resorting to pesticides. A good example of pest control is carried by dung beetles, which can colonize a dung heap within 24 hours, preventing flies from developing on them [5]. Similarly, by feeding on animal drops, the big-headed ant Pheidole megacephala killed eggs, larvae, and pupae of the common housefly Musca domestica, which resulted in reduced levels of flies and less fly-borne diseases [9].

Natural biological control has a world market value of 400,000 $\times 10^{6}$ US $\$$ billions [123, 124], much higher value then the 8.5 billion US\$ annually spent on insecticides [125]. No less than 230 invertebrate natural enemies are used in augmentative biology, and the majority of species belongs to insects [123], representing a marked share of about $0.130 \times 10^{6}$ US $\$$ billions [125] and thus with a high socioeconomic importance [126].

Another potential biocontrol undertaken by insects is control of weeds which compete with crops for nutrients and water. In fact, they are the target of much of the agrochemicals applied to crops worldwide. Herbicides comprise $47 \%$ of the world agrochemical sales compared with $29 \%$ of insecticides [127]. Weeding, usually by hand, accounts for up to $60 \%$ of total preharvest labor input in the developing world [128].

Introduced species can often become invasive, causing enormous environmental damage. For instance, in South Africa, the Indian fig opuntia, native to the southern United States, was 
introduced in 1659 as a drought fodder [129], by 1942 covered already 900,000 ha of rangelands, reducing the yield and accessibility of grass for cattle and small stock [130]. These negative effects were only reduced with the introduction of the scale insect Dactylopius opuntiae aiming its biocontrol, which markedly reduced O. ficus-indica density by 1948 [131]. Another good example was the use of snout beetles (Neochetina spp.) introduced from Australia that successfully controlled water hyacinths in Lake Victoria [132].

Seed predation, a particular case of weed biocontrol, can be an effective component on arable land, particularly at low weed densities [133]. By predating on seeds, ants may alter the abundance and local distribution of flowering plants in tropical and subtropical regions [134, 135]. In temperate regions, the most important seed eaters are most likely carabids (Carabidae: Coleoptera) [49]. Granivory by carabids has been confirmed by many authors (reviewed by [133]) and in arable fields can be as high as 1000 seeds. $\mathrm{m}^{-2}$.day ${ }^{-1}$, which can selectively influence the soil seed bank [133]. However, introduced species, even those used in biocontrol programs, can have important ecological effects on native species [136], and for this reason, deliberate introductions have generated great controversy [137, 138].

\subsubsection{Weathering processes}

In the soil, insects can have two major roles, they can be "litter transformers" or they can act as "ecosystem engineers" [139]. As litter transformers, insects fragment, or comminute, and humidify ingested plant debris, improving its quality as a substrate for later microbial decomposition. The feces of arthropods serve as nuclei for the accretion of soil aggregates, the basic unit of a soil's structure with a major role in maintaining its integrity, and are a significant factor in the formation of humus, which contributes to water and nutrient soil [140]. Termites and ants nests, with their incorporated fecal materials, waste dumps, or fungal gardens, provide rich substrates for the microbial degradation and mineralization of organic matter, resulting in the conversion of complex organic molecules into simpler, inorganic forms that can be used by plants [140]. As ecosystem engineers, they physically modify the habitat, directly or indirectly regulating the availability of resources to other species [141]. In the soil, this implies to alter the soil structure, as well as the mineral and organic matter composition and hydrology [142]. The tunneling and burrowing of arthropods provide channels for air passage and water infiltration and also serve to mix organic matter into the upper soil layers [140]. Some of the most important members of this guild are ants, termites, and dung beetles which, due to their dung burial activity, especially the digging tunnels functional types, are able to move large amounts of soil. Ants and termites are the pre-eminent earth movers in many regions of the world and may surpass earthworms in this capacity in some cases [140]. However, termites are probably the biggest contributors to plant litter breakdown among soil invertebrates and are the main agents of degradation, among the soil fauna, of the highly recalcitrant materials (cellulose and lignin) making up wood [140].

\subsubsection{Decomposition processes}

Insects play a vital role in waste biodegradation. Beetle larvae, flies, ants, and termites clean up dead plant matter, breaking down organic matter until it is fit to be consumed by fungi and bacteria. In this way, the minerals and nutrients of dead organisms become readily available in the 
soil for uptake by plants. Animal carcasses, for example, are consumed by fly maggots and beetle larvae [5]. Termites and leafcutter ants process large amounts of wood and leaves [143]. The decomposition of dead plant material can induce other services like a decline in the frequency and severity of forest fires [144].

Dung beetles are an important group of insects associated with the decomposition of animal manure. Their activity contributes to nutrient cycling. By burying dung under the soil surface, they prevent about $80 \%$ of nitrogen loss through ammonia $\left(\mathrm{NH}_{3}\right)$ volatilization $[5,145]$ and enhance soil fertility by increasing the amount of nitrogen available to plants through mineralization [146]. In their presence, carbon and minerals are recycled back to the soil, where they further decompose as humus for plants [5].

The role of insect herbivory in terrestrial ecosystems has only recently been considered an important and persistent control of ecosystem processes [41]. Severe insect outbreaks can provide mass pulses of nutrients, like for instance, cicada outbreaks provide mass pulses of nutrients that encourage growth of the forest trees they feed on. However, the less intense but more persistent insect herbivory present in many systems may also be an important influence on ecosystem processes [147, 148]. In addition, herbivores can influence ecosystem function by changing the nature of organic matter inputs to the soil $[149,150]$. Such changes can alter litter quality parameters, such as carbon to nitrogen and lignin to nitrogen ratios, inducing changes in decomposition rates and subsequent nutrient transformations [151]. Furthermore, the outputs of their activity, such as frass, honeydew, or even their carcasses, have distinctive chemical properties that can alter decomposition rates and nutrient release [152-154].

In the long term, selective herbivory can alter plant community composition, thus altering litter compositions available for decomposition [155]. Herbivory reduces canopy cover and increases precipitation reaching the ground or flowing into streams. Soil and litter insects affect soil porosity, as well as decomposition rate, both of which influence the rate of water movement through the substrate [41].

\subsection{Cultural}

\subsubsection{Physical and intellectual interactions with insects}

\subsubsection{Experiential use of insects and insect dependent wildlife}

Several activities depend even indirectly from insects, e.g., bioblitz is an intense period of biological survey aiming to record all the living species, including insects, within a selected area. Other examples include wildlife observation not only of insects (e.g., butterflies) but mainly of birds and other insectivorous animals like amphibians, reptiles, and small mammals. According to Losey \& Vaughan [28], Americans spend an estimated \$49 billion annually on hunting, fishing, and observing insect dependent wildlife, and a substantial proportion of this spending goes directly to insect observation. 


\subsubsection{Intellectual and representative interactions}

\subsubsection{Scientific}

Insects have inspired science and technology over time. When we think about insects and science, we immediately think about the fruit fly Drosophila melanogaster, which has been the source of many important scientific results over decades. Insects as biological model systems offer many advantages over mammalian models including ethical reasons, short generations, and exponential population growth. Another popular insect model is the wax moth Galleria mellonella, because it naturally hatches in bee hives, where it has to tolerate elevated temperatures. Reared at $37^{\circ} \mathrm{C}$, it serves as an excellent model system especially for bacterial infections, which could not be followed well at room temperature. Moreover, as a good correlation exists between virulence of several bacterial species in insect and mammalian models, G. mellonella is increasingly used as an infection model for human pathogens [156]. The red flour beetle Tribolium castaneum is also a popular model, since its development is more representative of other insects than D. melanogaster, a fact reflected in gene content and function. For example, T. castaneum has retained more ancestral genes involved in cell-cell communication than Drosophila, some being expressed in the growth zone crucial for axial elongation in short-germ development [157].

A project at Harvard University has created robotic insects, the project Robobees (http:// robobees.seas.harvard.edu/), inspired by bee's biology and hive behavior. There are many practical applications to these coordinated agile robotic insects, e.g., crop pollination, search, and rescue in the aftermath of a natural disaster, hazardous environment exploration, military surveillance, high resolution weather, and climate mapping or even traffic monitoring.

Similarly, insect products have received attention in order to develop new technology. For example, the unique structure of silk, its biocompatibility with living systems, its function as a tool for new materials engineering, and its thermal stability are only a few of the features that make it a promising material for many clinical functions [158]. Silk has been used in biomedical sutures for decades and has recently achieved US Food and Drug Administration approval for expanded biomaterials device utilities. The remarkable mechanical properties, versatile processing in an aqueous environment, biocompatibility, and controlled degradation suggest that silk (both native as well as recombinant) is an attractive biomaterial for controlled and sustained release, stabilization, and delivery of bioactive molecules [159]. Also the biopolymers chitin/chitosan, which have singular chemical and biological characteristics like biocompatibility, antibacterial properties, heavy metal ion chelation ability, gel-forming properties, hydrophilicity, and remarkable affinity to proteins, have been tested in for uses in medical and food industries [160].

Some useful models in building construction are termite mounds with their complicated network of tunnels and ventilation systems, in which several parameters (e.g., air quality, temperature and humidity) can be regulated in an efficient way [161].

Insects represent important tools in criminal investigations providing forensic information [162]. Forensic entomology is defined as the use of insects and other arthropods, such as mites, in medico criminal investigations [163]. 
The first recorded incident where insects were used in a criminal investigation was recorded in 13th century China [162]. The first application of forensic entomology in a modern court house occurred in 1850 in France, where entomological data were admitted as proof [164]. Later, Yovanovich [165] and Mégnin [166] were the first forensic examiners who attempted to evaluate insect succession on corpses, properly establishing the science of forensic entomology [167]. Insects allow the estimation of the time, at which a dead body was colonized [168]. Insects most often involved in the forensic investigations are true flies or Diptera. The predominant families in this order are Calliphoridae (blow flies), Sarcophagidae (flesh flies), and Muscidae (house flies). Calliphoridae and Sarcophagidae may arrive within minutes following death. Muscidae delay colonization until the body reaches bloat stages of decomposition [169].

Insects are highly sensitive to environmental changes, including those resulting from human activity, making them good indicators of ecological condition. Some species are capable of long distance dispersal, which enables them to find and colonize new patches. Other species are unable to fly and are therefore more vulnerable to disturbance. Due to some of their characteristics like small size, short life spans, and high reproductive rates and due to the fact that their abundances can change by several orders of magnitude on a seasonal or annual time scale (minimizing the time between disturbance and population adaptation to new conditions), insects are useful indicators of disturbance, more than are larger or longer-lived organisms with slower responses [41]. Studies have included the use of single species, higher taxa, assemblages and communities of, for example, dragonflies, ground beetles, tiger beetles, moths, butterflies, sawflies, and ants, and in habitats such as forests, grasslands, sand dunes, soils, urban areas, and mine sites [170]. However, there are some challenges, e.g., their taxonomy, which can pose an obstacle to their use in biomonitoring [171]. Aquatic insects are extremely important bioindicators of water quality and are frequently used following several well-established protocols. This fact is mainly due to the way how insects breathe in water, which makes them very sensitive to the amount of dissolved oxygen in water. Particular species are sensitive to dissolved oxygen, e.g., larvae of Plecoptera and Ephemeroptera which are pollution intolerant, whereas other taxa, such as particular species of chironomid midge larvae, can survive under deoxygenated conditions verging on anoxia [172].

\subsubsection{Educational}

Insects are frequently used as subjects of study in kindergartens and elementary schools. Several websites provide useful information regarding their biology and/or taxonomy. Among many others worldwide is the BBC website, several citizen science projects like the "UK ladybird survey" (http://www.ladybird-survey.org/ladybirds.aspx) or "the Lost Ladybug Project" in the U.S. (http://www.lostladybug.org/).

In the same way, insect zoos offer the opportunity to millions of people each year to observe live insects. Most insectariums and butterfly display offer some level of educational programming that promotes the appreciation and understanding of insect life, ranging from kindergarten to university level, and can also play a strong role in species conservation [173]. Although not currently updated, Saul-Gershenz [173] provides a list of selected insect exhibits built worldwide from 1797 to 2003. These are distributed as 26 in Europe, 9 in Asia, 29 in the US, 7 in Canada, 4 in Australia, 1 in New Zeeland, 6 in Latin America, 2 in Africa, and 1 in West India. 


\subsubsection{Heritage and cultural}

Fossilized insects in amber provide priceless information, not only regarding extant species at prehistoric times but also about details of their daily lives; for instance, it was recently discovered a 100-million-year-old evidence of brood care among scale insects fossilized in amber [174]. Other extraordinary fossils are the Meganeura sp. from Carboniferous period (resembled and are related to present-day dragonflies though not belonging to the modern order Odonata). Paleoentomology has contributed to the understanding of planet Earth history. For example, paleontological data can provide a good record of how biodiversity has responded to previous climatic change events [175].

\subsubsection{Entertainment}

No doubt insects have their role in literature, movies, and visual art, as well as their place as collection items, ornaments, and more generally as inspiration for creative expression. Insects are mentioned frequently in the writings of poets and philosophers, and the folklore of nearly every country refers to them [176].

There are several children stories which have used insects as their main characters like the timeless La Fontaine tale and The cicada and ant and more recent children movies like Bugs life, Antz, Bee movie or the TV series Maya the bee, adapted from the German book The Adventures of Maya the Bee. But literature and movies using insects are not restricted to children tales, e.g., the book Metamorphosis by Franz Kafka or the movies Empire of the ants and The fly. The death's-head hawk moth (genus Acherontia) was popularized by the movie Silent of the lambs. The TV series C.S.I. has also contributed to the awareness of entomology, with its famous entomologist Grissom solving several mysteries using insects.

In Australia, the didjeridu (commonly spelt didgeridoo) or yiraki is a very ancient aborigine instrument, which consists of a more-or-less straight piece of tree trunk or branch, hollowed out by the successive action of fire and termites to produce a gently flaring tube [177]. Also, musical composition was influenced by insects as exemplified by Rimsky-Korsakov in his Flight of the Bumblebee, which reproduced the familiar hum of the bees, as well as Joseph Strauss' inspiration revealed in Dragonfly [176].

In Asian countries, cicadas and crickets often are caged and kept as pets for their songs [178]. There are also some references in ancient Greek poetry to the use of locusts and cicadas, which were prized for their singing. There are many references in Greek epigrams to the keeping of insects as pets [179]. In Portugal, it is common as child to have silk moths as pets and feed them with mulberry leaves, and in the north of the country, during a religious ceremony called "Senhor de Matosinhos," crickets are sold as pets.

Cricket fighting is a popular "sport" in China and in other countries with Chinese migrants [180]. Cocoons of several species of saturniid moths and other families have been used to make hand rattles, ankle rattles, necklaces, purses or other artifacts in several cultures around the world. Native Americans and indigenous peoples in Africa and Mexico still continue to use moth cocoons [181]. Although authentic, some Mexican and African ankle rattles are possibly being produced for sale as musical instruments and ethnic objects, as well as for the original intended use in ceremonial dances [181]. 
Insects are also the target of many internet groups on Facebook, LinkedIn, at national and international level, stimulating the discussion and the sharing of information among professional and amateur entomologists.

\subsubsection{Aesthetic}

Certain invertebrates, most notably butterfly and beetle species, have been used for various esthetic and decorative purposes. Designs based on invertebrates have been employed in art, jewelry, fashion, and other decorative motifs. Scarab beetles were represented widely in art and ornaments [178] and were depicted in hieroglyphs and pictograms. But not only in Egypt, insect forms were converted into pictograms, but also these were present in Mayan and Chinese writing [182].

In visual arts, there are also several artists who depicted insects. Salvador Dali with his famous ants was the artist responsible for the designing of the poster for the International Silk Congress in 1957. Also, the graphic artist M. C. Escher recurred insects as subjects in his work.

Another widespread depiction of insects is present in mail stamps. Almost every country in the world has produced stamps with insects. The website "Insects on Stamps" (http://www. asahi-net.or.jp/ CH2M-NITU/indexe.htm) provides an index of stamps and even coins portraying insects arranged according to country, classified by species.

\subsubsection{Spiritual, symbolic, and other interactions with insects}

\subsubsection{Symbolic}

In the U.S., most states have adopted at least one insect symbol as a state insect, state butterfly, state bug, or state agricultural insect. For instance, New York state insect is the ladybird (ladybug) Coccinella novemnotata, the Kentucky agricultural insect is the honeybee and the Oklahoma state butterfly is the black swallowtail butterfly (see more at https://statesymbolsusa.org/categories/insect).

\subsubsection{Sacred and/or religious}

Insects have made a clear impact on several cultural aspects of human societies. For instance, they were present in many aspects of ancient Egypt, where scarab beetles were considered to be symbols of eternal life [178] and part of a religion with the scarab cult. However, there are much older references of insects as religions symbols from the late Paleolithic epoch $(10,000$ to 20,000 years ago), in the form of shamanistic "pendants" with the shape of beetles. In fact, among shamanic societies, there are a series of myths relating the creation of the world to beetles [183]. Also in Asian countries, insects have their roles as religious symbols with cicadas, for instance, being used as symbols of rebirth [178].

In Madagascar, the native B. cajani silk is processed to produce ritual burial shrouds and clothing items throughout the highlands. The "Landibe" shroud is essential for any respected dead person and is a sign of supreme honor [184]. The "Landibe" shroud is preferred over the one made with Bombyx mori silk in Madagascan ritual burials and for exhumations (a Madagascan habit to renew the shroud of mortal remains every 5 to 10 years) [60]. 
In Yemen, the Khidab, a black waterproof gall ink obtained from oak-galls of Quercus infectoria, which result from wasp action, is used for body painting during traditional ceremonies [185].

\subsubsection{Existence and bequest}

It is difficult to account with all the entomological societies existing in the world since the information is scattered and some of them are inactive, no longer existing, or even changed their names. Some societies do not have a webpage, and others only have a website in their native language, which largely increases the difficulty of documenting them. We produce a list which can be fully downloaded (see [186]). Our search returned about 286 societies (including regional branches) distributed worldwide. These were distributed as 127 in Europe, 113 in America (103 in North America, 8 in South America and 2 considering North, Central and South America), 23 in Asia, 9 in Oceania, 5 in Africa, 4 in the Middle East, and 5 international societies. The oldest society in the world still active is the Entomological Club of London founded in 1826, while the most recent, the Society of Overseas Nepalese Entomologists, funded in 2009.

Collections of insects and related arthropods constitute an enormous resource for biological information and document Earth's natural history [187]. The best estimate of how many collections exist is given by Evenhuis [188] that maintains a continually updated list of the world's insect and spiders collections, based on a previous list by Arnett et al. [189], with substantial additions and corrections. Evenhuis [188] listed 1819 entries. In fact, in some parts of the world, the sustainable collection of insects for collections and insectariums can provide economic opportunities for local populations, in alternative to destructive resource extraction such as logging, mining, or conversion of forest land to agricultural enterprises, such as cocoa, coffee, or oil palm plantations [190].

\section{Discussion}

Undeniably, insects are responsible for many of the ES provided by the ecosystems, where they occur (see Figure 2), covering all services categories (Provisioning, Regulating and Maintenance, and Cultural). The use of indicators of the services provided by insects will support the use of ES concept in an integrated approach (e.g., related to habitat status, drivers of change, pressures, new potential services, trade-offs), acknowledging the paramount importance of the most abundant and diverse group of organisms in the planet. From our search, we extracted (see Table 1) a total of 73 indicators, divided as 17 Provisional indicators, 27 Regulation and Maintenance indicators, and 29 Cultural indicators. The use of indicators has been recognized as a useful communication tool that facilitates the simplification of human-environmental systems high complexity, e.g., [13], they can be selected for mapping and assessment of ES [14] and to support specific management purposes involving ES trade-offs. As we can only protect and manage what we know, the proposed indicators might in this way give a contribution to the global International Platform of Biodiversity and Ecosystem Services and to the UN Natural Capital Accounting. Looking at the indicators that emerged from this review, it is clear that there are fewer indicators for the provisional services provided by insects. This may result from a negative attitude toward insects, especially in 

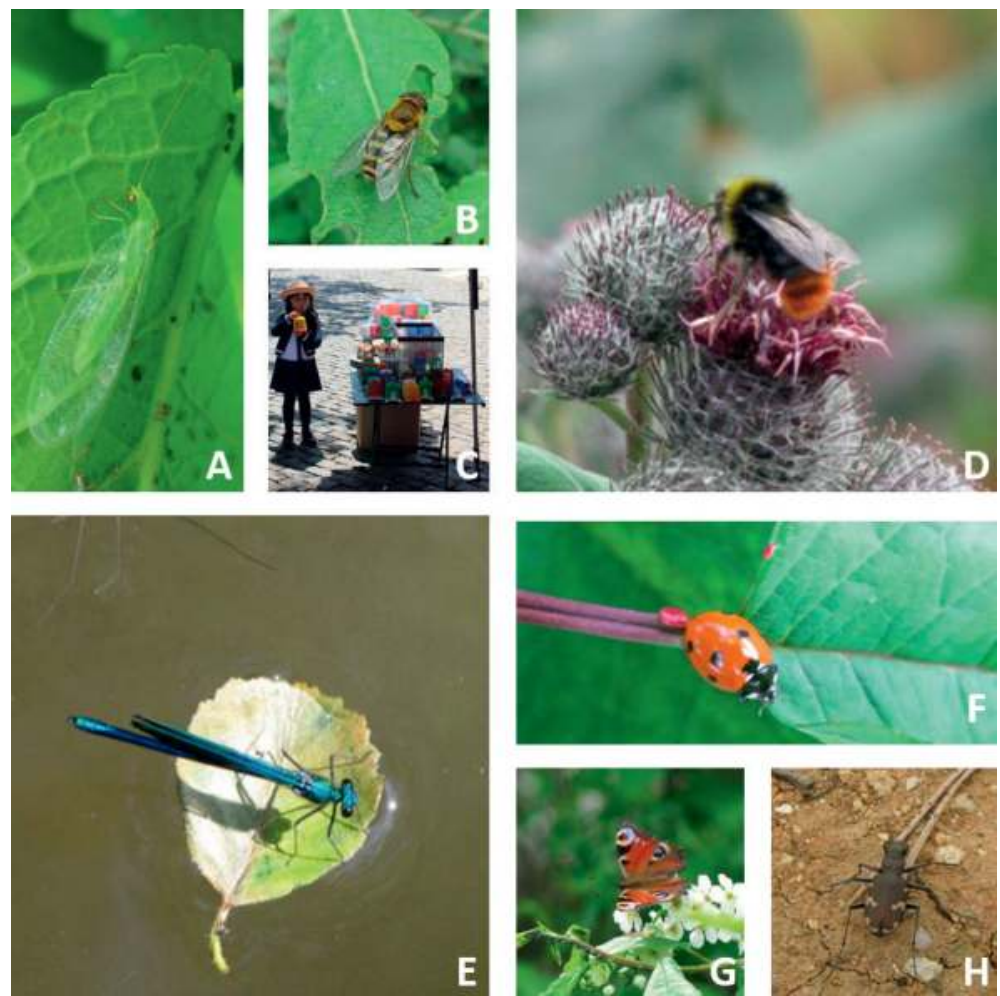

Figure 2. Different ecosystem services provided by insects. A - Lacewing adult: larvae are voracious predators of eggs and immature stages of many soft bodied insect pests; B-Syrphid fly: adults are pollinators, larvae are predators of agricultural pests; C-Cricket selling in the religious ceremony "Senhor de Matosinhos", Portugal; D-Bumblebee: pollinator; E-Damselfly: predator of other insects (e.g., mosquitoes); F-Ladybird: predator of agricultural pests; G- Butterfly: non-bee pollinator; $\mathrm{H}$-Tiger beetle: ground predator.

Western countries. Public perception of insects needs to be improved and the profiles of beneficial species must be raised [200] to fully preserve essential ES. The opposite occurs in more nature orientated cultures, in which apart from being important food sources, insects are also providers of materials and medicines. However, this potential is at risk, threatened by current environmental changes which are contributing to the degradation of insect habitats. The lack of important ES providers has greatly affected human lives around the world, e.g., the decline of pollinator species. Its consequences can be devastating, especially in a context of current predictions of food shortage to feed an increasing world population, since abiotic pollination or pollination carried by other animals is not so effective, which makes insect pollination an irreplaceable service.

Citing the famous entomologist Edward Osborne Wilson: "If insects were to vanish, the terrestrial environment would soon collapse into chaos" and "More respect is due the little things that run the world." 


\section{Acknowledgements}

This chapter was supported by Portuguese funds, through the national Foundation for Science and Technology - FCT to cE3c (UID/BIA/00329/2013). Thanks are also due, for the financial support to CESAM (UID/AMB/50017/2013), to FCT/MEC through national funds, and the cofunding by the FEDER, within the PT2020 Partnership Agreement and Compete 2020. A postdoctoral grant to OMCCA (SFRH/BPD/102965/2014) supported by FCT is also acknowledged.

\section{Author details}

Olga Maria Correia Chitas Ameixa ${ }^{1,2 *}$, António Onofre Soares ${ }^{2}$, Amadeu M.V.M. Soares ${ }^{1}$ and Ana I. Lillebø ${ }^{1}$

*Address all correspondence to: olga.ameixa@ua.pt

1 Biology Department and CESAM, University of Aveiro, Aveiro, Portugal

2 CE3C, Centre for Ecology, Evolution and Environmental Changes, Azorean Biodiversity Group, Department of Biology, University of the Azores, Portugal

\section{References}

[1] Thomas CD, Cameron A, Green RE, Bakkenes M, Beaumont LJ, Collingham YC, Erasmus BF, De Siqueira MF, Grainger A, Hannah L. Extinction risk from climate change. Nature. 2004;427(6970):145-148

[2] Hadfield MG. Introduction to the symposium: The crisis in invertebrate conservation. American Zoologist. 1993;33(6):497-498

[3] van Lenteren J. Ecosystem services to biological control of pests: Why are they ignored? Paper Presented at the Proc. Neth. Entomol. Soc. Meet; 2006

[4] Dunn RR. Global mapping of ecosystem disservices: The unspoken reality that nature sometimes kills us. Biotropica. 2010;42(5):555-557

[5] van Huis A, van Itterbeeck J, Klunder H, Mertens E, Halloran A, Muir G, Vantomme P. Edible insects: Future prospects for food and feed security. In: FAO Forestry Paper 171, editor. FAO Forestry Paper 171. Rome, Italy: Food and Agriculture Organization of the United Nations; 2003

[6] Cherniack EP. Bugs as drugs, part 1: Insects: The "new" alternative medicine for the 21st century. Alternative Medicine Review. 2010;15(2):124-135

[7] Dossey AT. Insects and their chemical weaponry: New potential for drug discovery. Natural Product Reports. 2010;27(12):1737-1757 
[8] Ratcliffe NA, Mello CB, Garcia ES, Butt TM, Azambuja P. Insect natural products and processes: New treatments for human disease. Insect Biochemistry and Molecular Biology. 2011;41(10):747-769. DOI: 10.1016/j.ibmb.2011.05.007

[9] Lockhart GJ. Ants and other great medicines. Partially Published Online by Jacobson, AL; 2007

[10] Jiang SJ. Anti-cancer insect medicinal materials in China. The Journal of Chinese Medicine. 1990;13(11):11-14

[11] Kettunen M, Vihervaara P, Kinnunen S, D'Amato D, Badura T, Argimon M, Ten Brink P. Socio-Economic Importance of Ecosystem Services in the Nordic Countries. Synthesis in the Context of the Economics of Ecosystems and Biodiversity (TEEB). Copenhagen: Nordic Council of Ministers; 2012

[12] Norris K. Biodiversity in the context of ecosystem services: The applied need for systems approaches. Philosophical Transactions of the Royal Society, B: Biological Sciences. 2012;367(1586):191-199. DOI: 10.1098/rstb.2011.0176

[13] Müller F, Burkhard B. The indicator side of ecosystem services. Ecosystem Services. 2012;1(1):26-30. DOI: 10.1016/j.ecoser.2012.06.001

[14] Maes J, Liquete C, Teller A, Erhard M, Paracchini ML, Barredo JI, Grizzetti B, Cardoso A, Somma F, Petersen JE, Meiner A, Gelabert ER, Zal N, Kristensen P, Bastrup-Birk A, Biala K, Piroddi C, Egoh B, Degeorges P, Fiorina C, Santos-Matín F, Narusevicius V, Verboven J, Pereira H, Bengtsson J, Gocheva K, Marta-Pedroso C, Snäll T, Estreguil C, Miguel JS, Perez-Soba M, Grêt-Regamey A, Lillebø AI, Malak DA, Condé S, Moen J, Czúcz B, Drakou EG, Zulian G, Lavalle C. An indicator framework for assessing ecosystem services in support of the EU biodiversity strategy to 2020. Ecosystem Services. 2016;17:14-23

[15] Millennium Ecosystem Assessment. Ecosystems and Human Well-Being: Synthesis. Washington, DC: Island Press; 2005

[16] Haines-Young R, Potschin M. Common International Classification of Ecosystem Services (CICES): Consultation on Version 4, August-ecember 2012. EEA Framework Contract No EEA/IEA/09/003. 2013. [Accessed: 20 May 2014]

[17] Saarikoski H, Jax K, Harrison PA, Primmer E, Barton DN, Mononen L, Vihervaara P, Furman E. Exploring operational ecosystem service definitions: The case of boreal forests. Ecosystem Services. 2015;14:144-157. DOI: 10.1016/j.ecoser.2015.03.006

[18] Mononen L, Auvinen AP, Ahokumpu AL, Rönkä M, Aarras N, Tolvanen H, Kamppinen M, Viirret E, Kumpula T, Vihervaara P. National ecosystem service indicators: Measures of social-ecological sustainability. Ecological Indicators. 2015. DOI: 10.1016/j.ecolind. 2015.03.041

[19] Benzies KM, Premji S, Hayden KA, Serrett K. State-of-the-evidence reviews: Advantages and challenges of including grey literature. Worldviews on Evidence-Based Nursing. 2006;3(2):55-61. DOI: 10.1111/j.1741-6787.2006.00051.x 
[20] Feld CK, Da Silva PM, Sousa JP, De Bello F, Bugter R, Grandin U, Hering D, Lavorel S, Mountford O, Pardo I, Pärtel M, Römbke J, Sandin L, Bruce Jones K, Harrison $P$. Indicators of biodiversity and ecosystem services: A synthesis across ecosystems and spatial scales. Oikos. 2009;118(12):1862-1871. DOI: 10.1111/j.1600-0706.2009.17860.x

[21] Fagerholm N, Käyhkö N, Ndumbaro F, Khamis M. Community stakeholders' knowledge in landscape assessments - mapping indicators for landscape services. Ecological Indicators. 2012;18:421-433. DOI: 10.1016/j.ecolind.2011.12.004

[22] van Huis A. Potential of insects as food and feed in assuring food security. Annual Review of Entomology. 2013;58:563-583

[23] Gullan PJ, Cranston PS. The Insects: An Outline of Entomology. 3rd ed. Blackwell Science; 2004

[24] MacEvilly C. Bugs in the system. Nutrition Bulletin. 2000;25(4):267-268. DOI: 10.1046/j.1467-3010.2000.00068.x

[25] Jongema Y. List of Edible Insects of the World. Wageningen University. Laboratory of Entomology; 2014. http://www.wur.nl/en/Expertise-Services/Chair-groups/PlantSciences/Laboratory-of-Entomology/Edible-insects/Worldwide-species-list.htm [Accessed March 2015]

[26] van Huis A, van Gurp H, Dicke M. The Insect Cookbook: Food for a Sustainable Planet. Columbia University Press; 2014

[27] Centre for the Promotion of Imports from developing countries. CBI market survey: The honey and other bee products market in the EU. In C. M. I. Database Ed; 2009. pp. 32

[28] Losey JE, Vaughan M. The economic value of ecological services provided by insects. Bioscience. 2006;56(4):311-323. DOI: 10.1641/0006-3568(2006)56[311:tevoes]2.0.co;2

[29] Ravindran V, Blair R. Feed resources for poultry production in Asia and the Pacific. World's Poultry Science Journal. 1993;49:219-235

[30] Wipfli MS. Terrestrial invertebrates as salmonid prey and nitrogen sources in streams: Contrasting old-growth and young-growth riparian forests in southeastern Alaska, USA. Canadian Journal of Fisheries and Aquatic Sciences. 1997;54(6):1259-1269

[31] Allan JD, Wipfli MS, Caouette JP, Prussian A, Rodgers J. Influence of streamside vegetation on inputs of terrestrial invertebrates to salmonid food webs. Canadian Journal of Fisheries and Aquatic Sciences. 2003;60(3):309-320. DOI: 10.1139/f03-019

[32] Baxter CV, Fausch KD, Carl Saunders W. Tangled webs: Reciprocal flows of invertebrate prey link streams and riparian zones. Freshwater Biology. 2005;50(2):201-220. DOI: 10.1111/j.1365-2427.2004.01328.x

[33] Kawaguchi Y, Taniguchi Y, Nakano S. Terrestrial invertebrate inputs determine the local abundance of stream fishes in a forested stream. Ecology. 2003;84(3):701-708. DOI: 10.1890/0012-9658(2003)084[0701:TIIDTL]2.0.CO;2 
[34] Baxter CV, Fausch KD, Murakami M, Chapman PL. Invading rainbow trout usurp a terrestrial prey subsidy from native charr and reduce their growth and abundance. Oecologia. 2007;153(2):461-470

[35] Nakano S, Murakami M. Reciprocal subsidies: Dynamic interdependence between terrestrial and aquatic food webs. Proceedings of the National Academy of Sciences of the United States of America. 2001;98(1):166-170. DOI: 10.1073/pnas.98.1.166

[36] Young MK, Rader RB, Belish TA. Influence of macroinvertebrate drift and light on the activity and movement of Colorado River cutthroat trout. Transactions of the American Fisheries Society. 1997;126(3):428-437

[37] Garman G. Use of terrestrial arthropod prey by a stream-dwelling cyprinid fish. Environmental Biology of Fishes. 1991;30(3):325-331. DOI: 10.1007/BF02028848

[38] Mobley JA. Birds of the World. Marshall Cavendish; 2008

[39] Liukkonen-Anttila T. Nutritional and genetic adaptation of galliform birds: Implications for hand-rearing and restocking. (PhD dissertation). Oulu, Finland: University of Oulu; 2001

[40] Crane E. History of honey. In: Crane E, editor. Honey, a Comprehensive Survey. Vol. 77. London: William Heinemann; 1975. pp. 439-448

[41] Schowalter TD. Insect Ecology: An Ecosystem Approach. 3rd ed. San Diego, CA: Elsevier/Academic Press; 2011

[42] Crane E. The World History of Beekeeping and Honey Hunting. New York, NY: Routledge; 1999

[43] Krell R. Value-added products from beekeeping. Food \& Agriculture Organization; 1996

[44] Liu W-W, Yang P, Chen X-M, Xu D-L, Hu Y-H. Cloning and expression analysis of four heat shock protein genes in Ericerus pela (Homoptera: Coccidae). Journal of Insect Science. 2014;14:9. DOI: 10.1093/jisesa/ieu032

[45] Ward G, editor. The Grove Encyclopaedia of Materials and Techniques in Art. Oxford University Press.; 2008

[46] Derry J. Investigating shellac: Documenting the process, defining the product. A study on the processing methods of shellac, and the analysis of selected physical and chemical characteristics. (Master Thesis Project-Based Master Thesis), University of Oslo; 2012

[47] Baboo B, Goswani DN. Processing, Chemistry and Application of Lac. New Delhi, India: Chandu Press; 2010

[48] Rossman JM. Commercial manufacture of edible films. In: Huber KC, Embuscado ME, editors. Edible Films and Coatings for Food Applications. Springer New York; 2009. pp. $367-390$

[49] Mills JS, White R. The Organic Chemistry of Museum Objects. Oxford: Butterworth Heinemann; 1994 
[50] Greig JB. WHO Food Additives Series 46: Cochineal Extract, Carmine, and Carminic acid. 1998. http://www.inchem.org/documents/jecfa/jecmono/v46je03.htm [Accessed: Nov 2014]

[51] Anelli CM, Prischmann-Voldseth DA. Silk batik using beeswax and cochineal dye: An interdisciplinary approach to teaching entomology. American Entomologist. 2009;55(2):95-105

[52] Theobald MM. Putting the red in redcoats. The Colonial Williamsburg Journal. 2012. http://www.history.org/foundation/journal/summer12/dye.cfm [Accessed: May 2015]

[53] Ferreira ES, Hulme AN, McNab H, Quye A. The natural constituents of historical textile dyes. Chemical Society Reviews. 2004;33(6):329-336

[54] Łagowska B, Golan K. Scale insects (Hemiptera, Coccoidea) as a source of natural dye and other useful substances. Aphids and Other Hemipterous Insects. 2009;15:151-167

[55] Cardon D. Le monde des teintures naturelles. Paris: Beeline; 2003

[56] Yong-woo L. Silk reeling and testing manual. FAO Agricultural Services Bulletin; 1999. p. 136

[57] Rafidiarimalala O. La sériciculture à Madagascar, technique d'élevage. Élevage (Madagascar): Mémoire de fin d'étude EESA: Université d'Antananarivo, Département; 1974

[58] Costa M. Manuel technique de sériciculture. Élevage des vers à soie. Vol. 2. Antananarivo: CITE, SAHA, Programme soie ONUDI Madagascar; 2004

[59] ONU. Développement de la sériciculture sur les Hauts plateaux, phase II, Madagascar. Rapport terminal. AG:D8:MAG :85 :006. Rome: Programme des Nations Unies pour le Développement; 1991

[60] CITE/BOSS Corporation. Étude nationale de la filière soie Analamanga, Ambalavao, Amoron'i Mania,Vakinakaratra, Itasy. Rapport final. Antananarivo, Madagascar: CITE; 2009

[61] Kolar J, Štolfa A, Strlič M, Pompe M, Pihlar B, Budnar M, Simčič J, Reissland B. Historical iron gall ink containing documents - Properties affecting their condition. Analytica Chimica Acta. 2006;555(1):167-174. DOI: 10.1016/j.aca.2005.08.073

[62] Schölten JS. Paper presented at the proc. European workshop on iron-gall ink corrosion. Amsterdam: Instituut Collectie Nederland; 1997

[63] Costa-Neto EM. Entomotherapy, or the medicinal use of insects. Journal of Ethnobiology. 2005;25(1):93-114. DOI: 10.2993/0278-0771(2005)25[93:EOTMUO]2.0.CO;2

[64] Jones R. Honey and healing through the ages. JAAS. 2009;1(1):2-5

[65] MolanPC. Theevidencesupporting theuse of honey as awound dressing. The International Journal of Lower Extremity Wounds. 2006;5(1):40-54. DOI:10.1177/1534734605286014 
[66] Izuta H, Chikaraishi Y, Shimazawa M, Mishima S, Hara H. 10-Hydroxy-2-decenoic acid, a major fatty acid from royal jelly, inhibits VEGF-induced angiogenesis in human umbilical vein endothelial cells. Evidence-based Complementary and Alternative Medicine. 2009;6(4):489-494

[67] Hattori N, Nomoto H, Fukumitsu H, Mishima S, Furukawa S. AMP N-1-oxide, a unique compound of royal jelly, induces neurite outgrowth from PC12 cells via signaling by protein kinase A independent of that by mitogen-activated protein kinase. Evidence based Complementary and Alternative Medicine. 2010;7(1):63-68

[68] Okamoto I, Taniguchi Y, Kunikata T, Kohno K, Iwaki K, Ikeda M, Kurimoto M. Major royal jelly protein 3 modulates immune responses in vitro and in vivo. Life Sciences. 2003;73(16):2029-2045

[69] Kumazawa S, Ueda R, Hamasaka T, Fukumoto S, Fujimoto T, Nakayama T. Antioxidant prenylated flavonoids from propolis collected in Okinawa, Japan. Journal of Agricultural and Food Chemistry. 2007;55(19):7722-7725. DOI: 10.1021/jf071187h

[70] Kujumgiev A, Tsvetkova I, Serkedjieva Y, Bankova V, Christov R, Popov S. Antibacterial, antifungal and antiviral activity of propolis of different geographic origin. Journal of Ethnopharmacology. 1999;64(3):235-240

[71] Paulino N, Teixeira C, Martins R, Scremin A, Dirsch VM, Vollmar AM, Abreu SR, de Castro SL, Marcucci MC. Evaluation of the analgesic and anti-inflammatory effects of a Brazilian green propolis. Planta Medica. 2006;72(10):899-906. DOI: 10.1055/s-2006-947185

[72] Li F, Awale S, Zhang H, Tezuka Y, Esumi H, Kadota S. Chemical constituents of propolis from Myanmar and their preferential cytotoxicity against a human pancreatic cancer cell line. Journal of Natural Products. 2009;72(7):1283-1287. DOI: 10.1021/np9002433

[73] Encyclopaedia Britannica. 2015. http://www.britannica.com/EBchecked/topic/112805/ Chinese-wax [Accessed: March 2015]

[74] Epstein WL, Kligman AM. Treatment of warts with cantharidin. Archives of Dermatology. 1958;77:508-511

[75] Gudger E. Stitching wounds with the mandibles of ants and beetles: A minor contribution to the history of surgery. American Medical Association; 1925

[76] Sherman RA, Hall MJ, Thomas S. Medicinal maggots: An ancient remedy for some contemporary afflictions. Annual Review of Entomology. 2000;45:55-81. DOI: 10.1146/ annurev.ento.45.1.55

[77] Sherman RA, Stevens H, Ng D, Iversen E. Treating wounds in small animals with maggot debridement therapy: A survey of practitioners. Veterinary Journal. 2007;173(1):138-143

[78] Kerridge A, Lappin-Scott H, Stevens J. Antibacterial properties of larval secretions of the blowfly, Lucilia sericata. Medical and Veterinary Entomology. 2005;19(3):333-337

[79] Pemberton RW. Insects and other arthropods used as drugs in Korean traditional medicine. Journal of Ethnopharmacology. 1999;65(3):207-216 
[80] Zimian D, Yonghua Z, Xiwu G. Medicinal insects in China. Ecology of Food and Nutrition. 1997;36(2-4):209-220. DOI: 10.1080/03670244.1997.9991516

[81] Han J, Inoue S, Isoda H. Effects of silkworm powder on glucose absorption by human intestinal epithelial cell line Caco-2. Journal of Natural Medicines. 2007;61(4):387-390

[82] Wenk E, Merkle HP, Meinel L. Silk fibroin as a vehicle for drug delivery applications. Journal of Controlled Release. 2011;150(2):128-141. DOI: 10.1016/j.jconrel.2010.11.007

[83] Elvin CM, Carr AG, Huson MG, Maxwell JM, Pearson RD, Vuocolo T, Liyou NE, Wong DCC, Merritt DJ, Dixon NE. Synthesis and properties of crosslinked recombinant proresilin. Nature. 2005;437(7051):999-1002

[84] Pearnchob N, Siepmann J, Bodmeier R. Pharmaceutical applications of shellac: Moistureprotective and taste-masking coatings and extended-release matrix tablets. Drug Development and Industrial Pharmacy. 2003;29(8):925-938. DOI: 10.1081/DDC-120024188

[85] Azouka A, Huggett R, Harrison A. The production of shellac and its general and dental uses: A review. Journal of Oral Rehabilitation. 1993;20(4):393-400

[86] Ma D, Wang Y, Yang H, Wu J, An S, Gao L, Xu X, Lai R. Anti-thrombosis repertoire of blood-feeding horsefly salivary glands. Molecular \& Cellular Proteomics. 2009;8(9):20712079. DOI: 10.1074/mcp.M900186-MCP200

[87] Eisner T, Aneshansley D. "Anting" in blue jays: Evidence in support of a food-preparatory function. Chemoecology. 2008;18(4):197-203. DOI: 10.1007/s00049-008-0406-3

[88] Clayton DH, Koop JA, Harbison CW, Moyer BR, Bush SE. How birds combat ectoparasites. The Open Ornithology Journal. 2010;3:41-71

[89] Longino JT. True anting by the capuchin, Cebus capucinus. Primates. 1984;25(2):243-245

[90] Hauser DC. Anting by gray squirrels. Journal of Mammalogy. 1964;136-138

[91] Bornemissza GF. The Australian dung beetle project 1965-1975. A.M.R.C. Review. 1976;30:1-30

[92] Fincher GT. The potential value of dung beetles in pasture ecosystems. Journal of Entomological Science. 1981;16

[93] Carlton RG, Goldman CR. Effects of a massive swarm of ants on ammonium concentrations in a subalpine lake. Hydrobiologia. 1984;111(2):113-117

[94] Mehner T, Ihlau J, Dörner H, Hölker F. Can feeding of fish on terrestrial insects subsidize the nutrient pool of lakes? Limnology and Oceanography. 2005;50(6):2022-2031

[95] Pray CL, Nowlin WH, Vanni MJ. Deposition and decomposition of periodical cicadas (Homoptera: Cicadidae: Magicicada) in woodland aquatic ecosystems. Journal of the North American Benthological Society. 2009;28(1):181-195

[96] Lal R, Hawksworth DL. Soil conservation and biodiversity. Paper presented at the Biodiversity of microorganisms and invertebrates: Its role in sustainable agriculture. Proc. First workshop on the ecological foundations of sustainable agriculture (WEFSA 1), London, UK, 26-27 July 1990; 1991 
[97] UNEP/CBD/COP/3/38. Report of the third ordinary meeting of the conference of the parties to the Convention on Biological Diversity. Argentina: Buenos Aires; 1996

[98] Ingram M, Nabhan GP, Buchmann SL. Our forgotten pollinators: Protecting the birds and bees. Global Pesticide Campaigner. 1996;6(4):1-12. http://www.apiservices.com/ articles/us/pollinators.htm [Accessed: Jan 2015]

[99] Free JB. Insect pollination of crops. London, UK: Academic Press; 1993

[100] Corlett RT. Honey bees in natural ecosystems. In: Hepburn HR, Radloff SE, editors. Honey Bees of Asia. Berlin Heidelberg: Springer-Verlag; 2011. pp. 215-225

[101] Partap U, Partap T. Managed crop pollination: The Missing dimension of mountain agricultural productivity mountain farming systems' Discussion Paper. Kathmandu: ICIMOD; 1997

[102] Sheffield CS, Ngo H, Azzu N. Report of the workshop on natural pollination services for agricultural production in apple orchards in the Hindu-Kush Himalayan region. In F. Report (Ed.); 2014

[103] Ahmad F, Partap U, Joshi SR, Gurung MB. Indigenous honeybees: Allies for mountain farmers. LEISA Magazine. 2004;20(4):12-13. http://www.agriculturesnetwork.org/ magazines/global/farming-with-nature/indigenous-honeybees [Accessed Dec 2014]

[104] USDA/NASS. California Almond Acreage Report, April 30; 2009, 2010

[105] Natural Resources Defense Council. Why we Need Bees Nature's Tiny Workers Put Food on our Tables. Bee Facts; 2011 https://www.nrdc.org/wildlife/animals/files/bees. pdf

[106] Ward R, Whyte A, James RR. A tale of two bees: Looking at pollination fees for almonds and sweet cherries. American Entomologist. 2010;56:172-179

[107] National Honey Board. National Honey Board Press Kit: Honey Industry Facts. 2. 2014. http://www.honey.com/images/uploads/general/NHB-Press-Kit-Honey-IndustryFacts_April_2014-1.pdf [Accessed Jan 2015]

[108] McGregor SE. Insect Pollination of Cultivated Crop-Plants. Vol.496. U.S.D.A Agriculture Handbook; 1976. p. 411

[109] Crane E, Walker P. Pollination Directory for World Crops. International Bee Research Association; 1984

[110] Rader R, Bartomeus I, Garibaldi LA, Garratt MPD, Howlett BG, Winfree R, Cunningham SA, Mayfield MM, Arthur AD, Andersson GKS, Bommarco R, Brittain C, Carvalheiro LG, Chacoff NP, Entling MH, Foully B, Freitas BM, Gemmill-Herren B, Ghazoul J, Griffin SR, Gross CL, Herbertsson L, Herzog F, Hipólito J, Jaggar S, Jauker F, Klein A-M, Kleijn D, Krishnan S, Lemos CQ, Lindström SAM, Mandelik Y, Monteiro VM, Nelson W, Nilsson L, Pattemore DE, Pereira NO, Pisanty G, Potts SG, Reemer M, Rundlöf M, Sheffield CS, Scheper J, Schüepp C, Smith HG, Stanley DA, Stout JC, Szentgyörgyii H, 
Taki H, Vergara CH, Viana BF, Woyciechowski M. Non-bee insects are important contributors to global crop pollination. Proceedings of the National Academy of Sciences. 2015. DOI: $10.1073 /$ pnas.1517092112

[111] Li Vigni I, Melati MR. Policoria ed interazioni ecologiche in Ricinus communis L. Giornale Botanico Italiano. 1995;129(2):147

[112] van der Pijl L. Principles of Dispersal in Higher Plants. Berlin, Heidelberg, New York: Springer-Verlag; 1982

[113] Li Vigni I, Melati MR. Examples of seed dispersal by entomochory. Acta Botanica Gallica. 1999;146(2):145-156. DOI: 10.1080/12538078.1999.10515813

[114] MacMahon JA, Mull JF, Crist TO. Harvester ants (Pogonomyrmex spp.): Their community and ecosystem influences. Annual Review of Ecology, Evolution, and Systematics. 2000:265-291

[115] Jones C, Lawton JH. Linking Species \& Ecosystems. Springer Science \& Business Media; 1995

[116] Jackson JK, Fisher SG. Secondary production, emergence, and export of aquatic insects of a Sonoran Desert stream. Ecology. 1986;67(3):629-638

[117] Gray LJ. Response of insectivorous birds to emerging aquatic insects in riparian habitats of a tallgrass prairie stream. American Midland Naturalist. 1993:288-300

[118] Burdon FJ, Harding JS. The linkage between riparian predators and aquatic insects across a stream-resource spectrum. Freshwater Biology. 2008;53(2):330-346. DOI:10.1111/j.13652427.2007.01897.x

[119] Sabo J, Power M. River-watershed exchange: Effects of riverine subsidies on riparian lizards and their terrestrial prey. Ecology. 2002;83(7):1860-1869

[120] Lacki MJ, Johnson JS, Dodd LE, Baker MD. Prey consumption of insectivorous bats in coniferous forests of north-Central Idaho. Northwest Science. 2007;81(3):199-205

[121] Konishi M, Itô Y. Early entomology in East Asia. In: Smith RF, Mittler TE, Smith CN, editors. History of Entomology. Palo Alto, CA: Annual Reviews Inc.; 1973. pp. 1-20

[122] Hagen KS, Franz JM. A history of biological control. In: Smith RF, Mittler TE, Smith CN, editors. In History of Entomology. Palo Alto, CA: Annual Reviews Inc.; 1973. pp. 433-476

[123] van Lenteren JC. The state of commercial augmentative biological control: Plenty of natural enemies, but a frustrating lack of uptake. BioControl. 2012;57(1):1-20

[124] Costanza R, d'Arge R, de Groot R, Farberk S, Grasso M, Hannon B, Limburg K, Naeem $\mathrm{S}, \mathrm{O}^{\prime}$ Neill RV, Paruelo J. The value of the world's ecosystem services and natural capital. Nature. 1997;387:253-260

[125] van Lenteren JC, editor. IOBC Internet Book of Biological Control, Version 6. Wageningen; 2012 
[126] Warner KD, Getz C. A socio-economic analysis of the north American commercial natural enemy industry and implications for augmentative biological control. Biological Control. 2008;45(1):1-10

[127] Woodburn AT. The market for agrochemicals: Present and Future. Paper Presented at the Proc. Brighton Crop Prot. Conf. - Weeds, Brighton, England; 1995

[128] Webb M, Conroy C. The socioeconomics of weed control on smallholder farms in Uganda. Paper presented at the Proc. Brighton Crop Prot. Conf. - Weeds; 1995

[129] Wells MJ, Balsinhas AA, Joffe H, Engelbrecht MW, Harding G, Stirton CH. A catalogue of problem plants in Southern Africa. Vol. 53. Memoirs of the botanical survey of South Africa; 1986. p. 658

[130] Du Toit R. The spread of prickly pear in the union. Farming in South Africa. 1942;17: 300-304

[131] Zimmerman HG, Moran VC, Hoffmann JH. Insect herbivores as determinants of the present distribution and abundance of invasive cacti in South Africa. In: Macdonald IAW, Kruger FJ, Ferrar AA, editors. The Ecology and Management of Biological Invasions in Southern Africa. Cape town, South Africa: Oxford University Press; 1986. pp. 269-274

[132] Wilson JR, Ajuonu O, Center TD, Hill MP, Julien MH, Katagira FF, Neuenschwander P, Njoka SW, Ogwang J, Reeder RH. The decline of water hyacinth on Lake Victoria was due to biological control by Neochetina spp. Aquatic Botany. 2007;87(1):90-93

[133] Honek A, Martinkova Z, Jarosik V. Ground beetles (Carabidae) as seed predators. European Journal of Entomology. 2003;100(4):531-544

[134] Brown JH, Reichman O, Davidson DW. Granivory in desert ecosystems. Annual Review of Ecology, Evolution, and Systematics. 1979:201-227

[135] Andersen A. Seed removal by ants in the mallee of northwestern Victoria ant-plant interactions in Australia. Springer; 1982. pp. 31-43

[136] Kindlmann P, Ameixa OMCC, Dixon AG. Ecological effects of invasive alien species on native communities, with particular emphasis on the interactions between aphids and ladybirds. BioControl. 2011;56(4):469-476. DOI: 10.1007/s10526-011-9384-4

[137] Simberloff D, Stiling P. Risks of species introduced for biological control. Biological Conservation. 1996;78(1):185-192

[138] Louda SM, Pemberton RW, Johnson MT, Follett P. Nontarget effects-the Achilles' heel of biological control? Retrospective analyses to reduce risk associated with biocontrol introductions. Annual Review of Entomology. 2003;48(1):365-396

[139] Lavelle P, Lattaud C, Trigo D, Barois I. Mutualism and biodiversity in soils. Plant and Soil. 1995;170(1):23-33. DOI: 10.1007/BF02183052

[140] Culliney T. Role of arthropods in maintaining soil fertility. Agriculture. 2013;3(4):629-659 
[141] Jones CG, Lawton JH, Shachak M. Organisms as Ecosystem Engineers Ecosystem Management. Springer; 1996. pp. 130-147

[142] Lobry de Bruyn L, Conacher A. The role of termites and ants in soil modification-a review. Australian Journal of Soil Research. 1990;28(1):55-93

[143] Kremen C, Chaplin-Kramer R. Insects as providers of ecosystem services: Crop pollination and pest control. In: Stewart AJA, New T, Lewis OT, editors. Insect Conservation Biology. Wallingford, UK: CABI; 2005. pp. 349-382

[144] Losey J, Vaughan M. Conserving the ecological services provided by insects. American Entomologist. 2008;54(2):113-114

[145] Gillard P. Coprophagous beetles in pasture ecosystems. The Journal of the Australian Institute of Agricultural Science. 1967;33:30-34

[146] Kazuhira Y, Hdeaki K, Takuro K, Toshiharu A. Nitrogen mineralization and microbial populations in cow dung, dung balls and underlying soil affected by paracoprid dung beetles. Soil Biology and Biochemistry. 1991;23(7):649-653

[147] de Mazancourt C, Loreau M, Dieckmann U. Can the evolution of plant defense lead to plant-herbivore mutualism? The American Naturalist. 2001;158(2):109-123

[148] Yang LH. Periodical cicadas as resource pulses in north American forests. Science. 2004;306(5701):1565-1567

[149] Schultz JC, Baldwin IT. Oak leaf quality declines in response to defoliation by gypsy moth larvae. Science. 1982;217(4555):149-151. DOI: 10.1126/science.217.4555.149

[150] Agrawal AA, Tuzun S, Bent E. Induced Plant Defenses against Pathogens and Herbivores: Biochemistry, Ecology, and Agriculture. APS Press; 1999

[151] Scott NA, Binkley D. Foliage litter quality and annual net N mineralization: Comparison across North American forest sites. Oecologia. 1997;111(2):151-159

[152] Hollinger DY. Herbivory and the cycling of nitrogen and phosphorus in isolated California oak trees. Oecologia. 1986;70(2):291-297

[153] Lovett GM, Ruesink AE. Carbon and nitrogen mineralization from decomposing gypsy moth frass. Oecologia. 1995;104(2):133-138

[154] Stadler B, Solinger S, Michalzik B. Insect herbivores and the nutrient flow from the canopy to the soil in coniferous and deciduous forests. Oecologia. 2001;126(1):104-113. DOI: $10.1007 / \mathrm{s} 004420000514$

[155] Ritchie ME, Tilman D, Knops JM. Herbivore effects on plant and nitrogen dynamics in oak savanna. Ecology. 1998;79(1):165-177

[156] Harding CR, Schroeder GN, Collins JW, Frankel G. Use of galleria mellonella as a model organism to study Legionella pneumophila infection. Journal of Visualized Experiments. 2013;(81):e50964. DOI: 10.3791/50964 
[157] The Tribolium Genome Sequencing Consortium. The genome of the model beetle and pest Tribolium castaneum. Nature. 2008;452(7190):949-955. DOI: http://www.nature. com/nature/journal/v452/n7190/suppinfo/nature06784_S1.html

[158] Vepari C, Kaplan DL. Silk as a biomaterial. Progress in Polymer Science. 2007;32(8): 991-1007

[159] Arai T, Freddi G, Colonna GM, Scotti E, Boschi A, Murakami R, Tsukada M. Absorption of metal cations by modified B. mori silk and preparation of fabrics with antimicrobial activity. Journal of Applied Polymer Science. 2001;80(2):297-303. DOI:10.1002/1097-4628(20010411)80:2<297::AID-APP1099>3.0.CO;2-Z

[160] Krajewska B. Membrane-based processes performed with use of chitin/chitosan materials. Separation and Purification Technology. 2005;41(3):305-312. DOI: 10.1016/j. seppur.2004.03.019

[161] Turner JS, Soar RC. Beyond biomimicry: What termites can tell us about realizing the living building. Paper presented at the Proc. 1st Int. Conf. Industrialized, Intelligent Construction; 2008

[162] Catts E, Goff ML. Forensic entomology in criminal investigations. Annual Review of Entomology. 1992;37(1):253-272

[163] Hall RD. Perceptions and status of forensic entomology. In: Byrd JH, Castner JL, editors. Forensic Entomology: The Utility of Arthropods in Legal Investigations. Boca Raton: CRC Press; 2001. pp. 1-15

[164] Bergeret M. Infanticide. Momification naturelle du cadavre. Découverte du cadavre d'un enfant nouveau-né dans une cheminée où il s'était momifié. Détermination de l'epoque de la naissance par la présence de nymphes et de larves d'insectes dans le cadavre, et par l'étude de leurs métamorphoses. Annales d'hygiène publique et de médecine légale. 1855;4:442-452

[165] Yovanovitch GP. Entomologie appliquée à la médicine légale. Paris: Ollier-Henry; 1888

[166] Mégnin P. La faune de cadavres. Application de l'entomologie a la médicine légale. Paris: Encyclopdie scientifique des Aides-Mémoire, Masson, Paris, Gauthier-Villars; 1894

[167] AmendtJ, Krettek R, Zehner R. Forensic entomology. Naturwissenschaften. 2004;91(2):5165. DOI: 10.1007/s00114-003-0493-5

[168] Greenberg B. Flies as forensic indicators. Journal of Medical Entomology. 1991;28(5): 565-577

[169] Joseph I, Mathew DG, Sathyan P, Vargheese G. The use of insects in forensic investigations: An overview on the scope of forensic entomology. Journal of Forensic Dental Sciences. 2011;3(2):89

[170] McGeoch MA. The selection, testing and application of terrestrial insects as bioindicators. Biological Reviews. 1998;73(02):181-201 
[171] New T. Taxonomic focus and quality control in insect surveys for biodiversity conservation. Australian Journal of Entomology. 1996;35(2):97-106

[172] Hodkinson I, Jackson J. Terrestrial and aquatic invertebrates as bioindicators for environmental monitoring, with particular reference to mountain ecosystems. Environmental Management. 2005;35(5):649-666. DOI: 10.1007/s00267-004-0211-x

[173] Saul-Gershenz L. Insect zoos. In: Resh VH, Cardé RT, editors. Encyclopedia of Insects. 2nd ed. San Diego: Academic Press; 2009. pp. 516-523

[174] Wang B, Xia F, Wappler T, Simon E, Zhang H, Jarzembowski EA, Szwedo J. Brood care in a 100-million-year-old scale insect. eLife. 2015;4:e05447. http://www.ncbi.nlm.nih. gov/pmc/articles/PMC4378507/ [Accessed Feb 2015]. DOI: 10.7554/eLife.05447

[175] Ameixa OMCC Aphids in a changing world. In: Kindlmann P, Dixon AFG, Michaud JP, editors. Aphid biodiversity under environmental change. Dordrecht: Springer; 2010. pp. 21-40

[176] Frost SW. Insect Life and Insect Natural History. New York: Dover Publications, Inc.; 1959

[177] Fletcher N. The didjeridu (didgeridoo). Acoustics Australia. 1996;24(1):11-15

[178] Clausen LW. Insect fact and folklore. New York, NY: MacMillan Co.; 1954

[179] Fain GL. Ancient Greek epigrams: Major poets in verse translation. University of California Press; 2010

[180] Xing-Bao J, Kai-Ling X. An index-catalogue of Chinese Tettigoniodea (Orthopteroidea: Grylloptera). Journal of Orthopaedic Research. 1994:15-41

[181] Peigler RS. Non-sericultural uses of moth cocoons in diverse cultures. Paper presented at the Proc. Denver Museum of Natural History; 1994

[182] Hogue CL. Cultural entomology. Annual Review of Entomology. 1987;32(1):181-199. DOI: 10.1146/annurev.en.32.010187.001145

[183] Cambefort Y. Beetles as religious symbols. Cultural Entomology Digest. Issue 1; 1993. http://www.insects.org/ced1/beetles_rel_sym.html (Accessed May 2015)

[184] Rakotoniaina NS. Vers une démarche de gestion durable des ressources de la forêt sclérophylle de moyenne altitude d'Arivonimamo II- Madagascar. (Thèse de doctorat). Madagascar: Université d'Antananarivo; 2009

[185] Schönig H. Traditional cosmetics of women in Yemen. The black dye hiḍāb: Traditional and modern ways of fabrication. Paper presented at the Proc. Seminar for Arabian Studies; 1996

[186] Ameixa OMCC, Soares AOM, Soares AMVM, Lillebø AI. Worldwide list of entomological societies. 2017. Available at: www.cesam.ua.pt/index.php?tabela=pessoaldetai $1 \&$ menu $=95 \&$ user $=981$ 
[187] Nishida GM. Museums and display collections. In: Resh VH, Cardé RT, editors. Encyclopedia of Insects. 2nd ed. San Diego: Academic Press; 2009. pp. 680-684

[188] Evenhuis NL. Abbreviations for insect and spider collections of the world. 2015. Available at: http://hbs.bishopmuseum.org/codens/codens-inst.html [Accessed: November 2015]

[189] Arnett RA Jr, Samuelson GA, Nishida GM. The insect and spider collections of the world. 2nd ed. Gainesville FL: Sandhill Crane Press; 1993

[190] Small RD. Becoming unsustainable? Recent trends in the formal sector of insect trading in Papua New Guinea. Oryx. 2007;41(03):386-389

[191] Leather SR. Taxonomic chauvinism threatens the future of entomology. Biologist. 2009;56(1):10-13 